\title{
Transconjugation for Molecular Genetic Study of Streptomyces platensis Producing Transglutaminase
}

\author{
Se-Joung Bae, Yang-Ho Jo and Sun-Uk Choi* \\ Department of Food Science and Biotechnology, Kyungnam University, Masan 631-701, Korea
}

Received November 9, 2009 /Accepted January 21, 2010

\begin{abstract}
Streptomyces platensis YK-2, newly isolated from forest soil, produces transglutaminase (TGase), which catalyses an acyl transfer reaction between the primary grade amine and protein or $\gamma$-carboxyamide group of peptide bound glutamine residues. For a molecular genetic study of $S$. platensis, an effective transformation method was established by using a conjugal transfer of DNA from Escherichia coli to spores of actinomycetes. The highest transconjugation frequency of $S$. platensis was obtained on an MS medium containing $50 \mathrm{mM} \mathrm{MgCl}_{2}$, using $5 \times 10^{7} \mathrm{E}$. coli as a DNA donor and $1 \times 10^{8}$ spores without heat treatment as a host. We also identified that $S$. platensis contains a single attB site within an ORF encoding a pirin-homolog, and that its att $B$ site sequence shows high homology to that of $S$. logisporoflavis. In addition, it was confirmed by phenotypic analyses of exconjugants that the introduction of heterologous DNA into the $a t t B$ site of the $S$. platensis chromosome does not affect its morphological differentiation and TGase production.
\end{abstract}

Key words : Streptomyces platensis YK-2, transformation, attB site, transglutaminase

\section{서 론}

식품단백질의 물성과 유연성을 개선하고 식품단백질 중의 lysine 보호, 내열성과 보수성 강화, 저온에서의 겔화, 탄력성 과 수분함유 능력 향상, 가용성과 기능성 향상 등의 특성 변화 를 도와주는 transglutaminase (TGase, protein-glutamine $\gamma$ glutamyltransferase: E.C.2.3.2.13)는 포유동물의 모발, 뇌, 간장 등의 생체 내에 널리 존재하며 조류, 어류, 식물 등에도 존재하 는 것으로 알려져 있다[8,12]. 그러나 포유동물 유래와 다르게 미생물 유래의 TGase는 칼슘 비의존성, 열안정성, 활성의 넓은 $\mathrm{pH}$ 범위 등의 반응특성을 가지고 있어 산업적으로 적용하기 쉽기 때문에 더욱 주목받게 되었다. 미생물 유래의 microbial transglutaminase (MTG)는 방선균인 Streptoverticillium sp. S-8112 [9]에서 처음 분리되었으며 우수한 TGase생산 균주를 획득하기 위한 연구는 끝임 없이 진행되고 있다. 최근 대구지 역에서 새로운 MTG를 생산하는 방선균, Streptomyces platensis $\mathrm{YK}-2$ 가 신규로 분리되어 연구되었다[22]. 하지만 S. platensis YK-2가 생산하는 MTG는 우수한 특성을 가졌음에도 불구하 고 생산량의 한계로 산업적인 활용이 쉽지 않기 때문에 분자 생물학적인 방법을 통한 생산균주의 개량이 필요한 상황이다. 그러나 방선균은 외부 유전자에 대한 강력한 제한계, 효율적 인 형질전환 시스템의 부재, 재조합체의 불안전성 등의 특징 을 가지고 있어 분자생물학적인 연구가 쉽지 않다[2,13].

지금까지 방선균의 형질전환에는 주로 protoplast법과

*Corresponding author Tel : +82-55-249-2258, Fax : +82-55-249-2995

E-mail : suchoi@kyungnam.ac.kr electroporation법 등이 사용되었다. 그러나 이들 방법들은 형 질전환율이 높지 않거나 적용되는 방선균이 제한적이라는 단 점이 있다. 최근에 이러한 문제를 극복하기 위하여 Escherichia coli를 공여체로 사용하여 단일가닥 DNA를 세포 내로 도입하 는 접합전달법(transconjugation)이 도입되었다[7,11,17]. 접합 전달법은 E. coli 내에서 재조합 플라스미드의 구축 및 조작이 가능하며 구축된 플라스미드를 방선균으로 직접 전달할 수 있어 유전자 클로닝 및 유전자 파괴, 변이유전자 회복 등에 폭 넓게 사용되고 있다. E. coli를 이용한 접합전달이 Mazodier 등[15]에 의해 처음으로 보고되어진 이후, 방선균에 존재하는 메틸화된 DNA의 제한계를 극복하기 위해 DNA의 공여균주 (donor)로 메틸화가 결손된 E. coli ET12567/pUZ8002 [3,16, 20]을 사용함으로써 보다 다양한 속(genus)의 방선균에 적용 할 수 있게 되었다[14,21]. 또한 현재 사용되고 있는 접합전달 을 위한 벡터들 가운데 방선균의 chromosome에 존재하는 attB site로 integration되는 $p h \mathrm{C} 31$ 유래의 attachment site $(a t t P)$ 와 integrase $(i n t)$ 기능을 가진 벡터들이 가장 유용한 것 으로 알려져 있다[7,20]. 이러한 벡터들은 접합전달을 통해 $E$. coli로부터 방선균으로 전달되고 전달된 벡터의 attP site는 integrase에 의해 방선균 chromosome의 attB site로 삽입된다. 그러나 새로운 MTG를 생산하는 S. platensis YK-2에 대한 형질 전환방법은 아직 연구된 봐 없다.

따라서 본 연구에서는 새로운 MTG를 생산하는 신규 방선 균, S. platensis YK-2의 분자생물학적인 연구를 위해 접합전달 법을 이용한 고효율 형질전환방법을 구축하였으며 attP site가 삽입되는 $S$. platensis YK-2의 genomic attB site에 대하여 연구 하였다. 


\section{재료 및 방법}

\section{사용균주 및 plasmids}

본 연구에 사용된 방선균은 대구지역에서 분리된 S. platensis YK-2 [22]로 TGase를 생산하며 본 균주의 포자는 접합전 달의 수용체로서 사용하였다. E. coli XL-10-Gold는 클로닝을 위한 숙주로 사용하였으며 메틸화가 결손된 E. coli ET12567/ $\mathrm{pUZ8002를} \mathrm{접합전달의} \mathrm{DNA} \mathrm{공여균주로} \mathrm{사용하였다.} \mathrm{phK} 31$ 유래의 attachment site (attP)와 integrase (int) 기능을 가진 pSET152 $(5.7 \mathrm{~kb})$ [3]를 접합전달의 부위-특이적 재조합(sitespecific recombination) 벡터로 사용하였다. 본 벡터가 접합전 달을 통해 숙주세포 내로 전달되면 integrase의 도움으로 방선 균 chromosome의 attB site로 삽입되어 유전자 재조합 (recombination)이 이어서 일어나기 때문에 본 논문의 결과들 은 접합전달효율(transconjugation frequency)로 나타냈다.

\section{배지 및 배양조건}

S. platensis ATCC 49173의 포자생산용 배지는 ISP2 한천배 지(yeast extract $4 \mathrm{~g} / \mathrm{l}$, malt extract $10 \mathrm{~g} / \mathrm{l}$, glucose $4 \mathrm{~g} / \mathrm{l}$, agar $20 \mathrm{~g} / \mathrm{l}, \mathrm{pH}$ 7.0 7.4)를 사용하였으며 접합전달을 위한 배지로 는 AS-1 (yeast extract $1 \mathrm{~g} / \mathrm{l}$, L-alanine $0.2 \mathrm{~g} / \mathrm{l}$, L-arginine $0.2 \mathrm{~g} / \mathrm{l}$, L-asparagin $0.5 \mathrm{~g} / \mathrm{l}$, soluble starch $5 \mathrm{~g} / \mathrm{l}, \mathrm{NaCl} 2.5$ $\mathrm{g} / \mathrm{l}, \mathrm{Na}_{2} \mathrm{SO}_{4} 10 \mathrm{~g} / \mathrm{l}$, agar $20 \mathrm{~g} / \mathrm{l}, \mathrm{pH}$ 7.5), ISP4 (soluble starch $10 \mathrm{~g} / \mathrm{l}, \mathrm{K}_{2} \mathrm{HPO}_{4} 1 \mathrm{~g} / \mathrm{l}, \mathrm{MgSO}_{4} \cdot 7 \mathrm{H}_{2} \mathrm{O} 1 \mathrm{~g} / \mathrm{l}, \mathrm{NaCl} 1 \mathrm{~g} / \mathrm{l}$, $(\mathrm{NH} 4)_{2} \mathrm{SO}_{4} 2 \mathrm{~g} / \mathrm{l}, \mathrm{CaCO}_{3} 2 \mathrm{~g} / \mathrm{l}, \mathrm{FeSO}_{4} \cdot 7 \mathrm{H}_{2} \mathrm{O} 0.001 \mathrm{~g} / \mathrm{l}$, $\mathrm{MnCl}_{2} \cdot 4 \mathrm{H}_{2} \mathrm{O} 0.001 \mathrm{~g} / \mathrm{l}, \mathrm{ZnSO}_{4} \cdot 7 \mathrm{H}_{2} \mathrm{O} 0.001 \mathrm{~g} / \mathrm{l}$, agar $15 \mathrm{~g} / \mathrm{l}$, $\mathrm{pH}$ 7.0 7.4), MS배지(mannitol $20 \mathrm{~g} / \mathrm{l}$, soya flour $20 \mathrm{~g} / \mathrm{l}$, agar $20 \mathrm{~g} / \mathrm{l}$ )를 사용하였다. 또 $E$. coli의 일반배양 및 형질전환 을 위해 Luria Bertani (LB)배지를 이용하여 $37^{\circ} \mathrm{C}$ 에서 $180 \mathrm{rpm}$ 으로 진탕배양 하였다.

\section{DNA 조작 및 분리}

대장균에서의 DNA 조작은 Sambrook 등[19]의 방법을 사 용하였고 S. platensis 에서의 DNA 조작은 Kieser 등[10]의 방 법을 사용하였으며 S. platensis 접합전달체의 total DNA는 Rao 등[18]의 방법으로 회수하였다. Southern blot hybridization을 위해 DIG High Prime DNA Labeling and Detection Starter Kit II (Roche Applied Science, Tokyo, Japan)와 pSET152의 $0.5 \mathrm{~kb}$ apramycin-resistant 유전자 단편을 probe 로 사용하였다. DNA 염기서열 결정은 $\mathrm{pSET} 152$ 의 attP site에 서 $100 \mathrm{bp}$ 떨어진 부분의 염기서열을 이용하여 ATTPR primer (5'-CTGGGTGGGTTACACGACGCCCCT-3')를 제작하여 진 행하였다.

\section{접합전달방법}

E. coli에서 S. platensis으로 plasmid의 접합전달은 Kieser
등[10]이 확립한 방법에 변형하여 수행하였다. pSET152를 포 함하는 공여균주 E. coli ET12567/pUZ8002은 apramycin (50 $\mu \mathrm{g} / \mathrm{ml}$; 이하 Apr), chloramphenicol $(25 \mu \mathrm{g} / \mathrm{ml}$; 이하 $\mathrm{Cm})$, kanamycin $(50 \mu \mathrm{g} / \mathrm{ml}$; 이하 $\mathrm{Km})$ 이 첨가된 $\mathrm{LB}$ 배지에 접종한 후, optical density 600 에서 0.4 가 될 때까지 배양하였다. $S$. platensis의 생육에 저해가 되는 첨가된 항생제를 제거하기 위 해 동량의 LB 배지로 두 번 세척한 후 0.1 배의 LB 배지로 재현탁하여 S. platensis 와의 접합전달을 위한 공여균주로 사 용하였다. 열처리하지 않은 $1 \times 10^{7}$ 의 S. platensis 포자를 $2 \times Y \mathrm{YT}$ 배지 $0.5 \mathrm{ml}$ 로 현탁한 후 준비된 공여균주의 현탁액 $0.5 \mathrm{ml}$ $\left(2.5 \times 10^{7}\right)$ 와 잘 혼합한 다음, 원심분리하여 상징액을 제거한 뒤 얻어진 pellet을 $10 \mathrm{mM}$ 의 $\mathrm{MgCl}_{2}$ 를 포함한 4종류(AS-1, $\mathrm{ISP} 2, \mathrm{ISP} 4, \mathrm{MS})$ 의 고체배지에 도말하고 $28^{\circ} \mathrm{C}$ 에서 $16 \sim 20$ 시간 동안 정치배양하였다. 형질전환체의 선별을 위해 $1.5 \mathrm{ml}$ 의 살 균수에 $0.5 \mathrm{mg}$ 의 nalidixic acid (이하 Nal)와 $1 \mathrm{mg}$ 의 Apr을 첨가하여 배지위에 중첩시킨 후, $28^{\circ} \mathrm{C}$ 에서 6 일간 더 배양하였 다. 선발된 접합전달체를 $\mathrm{Nal}(25 \mu \mathrm{g} / \mathrm{ml})$ 및 $\mathrm{Apr}(25 \mu \mathrm{g} / \mathrm{ml})$ 이 함유된 선택 배지에 계대배양하여 얻어진 균주들의 chromosome DNA를 추출하고 PCR에 의해 형질전환 유무를 확인하 였다. 본 연구를 통해 얻어진 모든 접합전달효율(transconjugation frequency)은 접합전달실험에 사용된 포자수 대비 획 득된 접합전달체수의 비율로 나타내었다.

\section{염기서열의 accession number}

본 논문에 보고된 S. platensis ATCC 49173의 attB site의 염기서열은 GeneBank에 accession number AB531501로 등록 되었다.

\section{결과 및 고찰}

\section{접합전달을 위한 최적배지}

S. platensis의 접합전달을 위한 최적배지를 조사하기 위해 지금까지 접합전달법에 사용된 배지 4종(AS-1, ISP2, ISP4, $\mathrm{MS})$ 을 선정하여 연구하였다. 이미 수행된 연구들을 보면 접합 전달에 사용되는 고체배지에 따라 접합전달효율이 크게 영향 받는 것을 알 수 있다[4]. 본 연구에 사용된 MS와 AS-1배지는 방선균의 접합전달에 가장 많이 사용되는 배지이며 $[7,10,17]$, ISP2배지는 S. lavendulae FRI-5 [11]에, ISP4는 희소방선균 Kitasatospora setae [4]의 접합전달에 사용된 최적배지이다. Table 1 과 같이 4 종의 배지를 각각 S. platensis의 접합전달실험 에 적용해 본 결과 $\mathrm{AS}-1, \mathrm{ISP} 4, \mathrm{MS}$ 의 경우에는 접합전달체가 형성되어 본 실험에 사용 가능하다는 것이 확인 되었다. 그러 나 ISP2의 경우에는 S. platensis의 포자생산용 최적배지임에도 불구하고 접합전달체를 전혀 형성하지 못해 S. platensis의 접 합전달에는 부적합한 것으로 확인되었다(Table 1). 또 형질전 환체가 형성된 3 종의 배지 중에서 접합전달효율은 MS가 가장 
Table 1. Effects of medium on transconjugation efficiency

\begin{tabular}{cc}
\hline Medium $^{\mathrm{a}}$ & Transconjugation $^{- \text {frequency }^{\mathrm{b}}}$ \\
\hline MS & $2.3 \times 10^{-6}$ \\
ISP4 & $1.4 \times 10^{-6}$ \\
AS-1 & $6.5 \times 10^{-8}$ \\
ISP2 & - \\
\hline
\end{tabular}

${ }^{\mathrm{a}}$ Each medium contains $10 \mathrm{mM} \mathrm{MgCl}$.

${ }^{b}$ Values represent average frequencies from three independent experiments.

- indicates no exconjugant.

높았고 ISP4와 AS-1의 순서였지만 ISP4의 경우 MS와 거의 차이가 없는 것으로 밝혀져 MS와 ISP4는 S. platensis의 접합전 달을 위해 모두 사용 가능한 것으로 판단된다. 그러나 가장 낮은 접합전달효율을 보인 AS-1의 경우에는 MS보다 35배나 낮은 효율을 보여 배지간의 차이가 대단히 크다는 것을 확인 할 수 있었다. 그러므로 MS배지를 S. platensis의 접합전달을 위한 최적배지로 선정하고 이후 실험에 계속 사용하였다.

\section{포자의 열처리 효과}

방선균 포자에 일정 시간 동안 열처리를 하였을 경우 접합 전달효율이 상승하는 것으로 밝혀졌다[6,10,15]. 이러한 현상 은 열처리가 포자의 발아를 유도하여 접합전달의 효율이 향상 되거나[16] 방선균이 가진 제한계를 일시적으로 약화시킴으로 써 효율이 증가되는 것으로 알려져 있다[1,6]. 따라서 S. platensis 포자에 대한 최적 열처리 온도를 결정하기 위하여 $30^{\circ} \mathrm{C}$ 에서 $60^{\circ} \mathrm{C}$ 까지 $5^{\circ} \mathrm{C}$ 간격으로 각각 10 분간 열처리하고 처리하 지 않은 대조군과 비교하여 열처리에 대한 포자의 생존율을 조사하였다. 그 결과 Fig. 1 과 같이 열처리 온도가 올라갈수록 포자의 생존율이 떨어졌으며 $45^{\circ} \mathrm{C}$ 부터는 급격하게 떨어져 $60^{\circ} \mathrm{C}$ 에서는 전혀 생존하지 못했다. 접합전달을 위한 열처리조

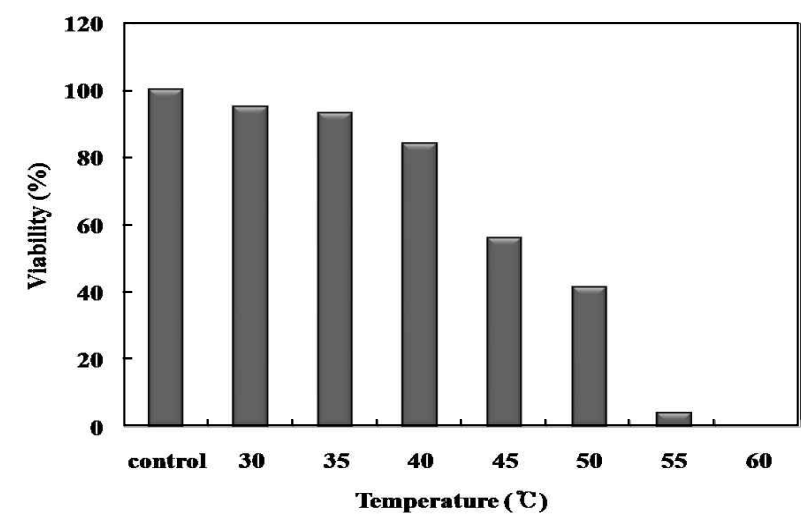

Fig. 1. Effects of temperature on the viability of $S$. platensis spores. Spores $\left(10^{3} / \mathrm{ml}\right)$ in $2 \times Y \mathrm{~T}$ medium were incubated for $10 \mathrm{~min}$ at the temperature indicated. The data are the average of three independent experiments, and expressed as a percent of the colony count obtained in the absence of heat treatment (control).
Table 2. Effects of heat treatment of spores on transconjugation efficiency

\begin{tabular}{cc}
\hline $\begin{array}{c}\text { Temperature of } \\
\text { heat treatment }\end{array}$ & Transconjugation frequency $^{\mathrm{b}}$ \\
\hline No heat treatment & $1.4 \times 10^{-6}$ \\
$30^{\circ} \mathrm{C}$ & $7.9 \times 10^{-7}$ \\
$35^{\circ} \mathrm{C}$ & $7.0 \times 10^{-7}$ \\
$40^{\circ} \mathrm{C}$ & $4.9 \times 10^{-7}$ \\
$45^{\circ} \mathrm{C}$ & - \\
\hline
\end{tabular}

${ }^{\mathrm{a}}$ The heat treatment of spores was performed for $10 \mathrm{~min}$.

${ }^{b}$ Values represent average frequencies from three independent experiments.

- indicates no exconjugant.

건으로는 $50 \%$ 이상의 생존율이 보장되는 것이 좋기 때문에 $56 \%$ 의 생존율을 보인 $45^{\circ} \mathrm{C}$ 까지 접합전달을 위한 열처리 온도 에 포함하여 접합전달효율을 조사하였다. 그 결과 열처리를 하지 않은 대조군에 비해 열처리를 한 모든 실험군에서 접합 전달효율이 떨어졌으며 특히 $45^{\circ} \mathrm{C}$ 의 열처리에서는 접합전달 체가 전혀 형성하지 못했다(Table 2). 그러므로 S. platensis YK-2의 경우에는 포자에 대한 열처리가 오히려 접합전달효율 을 떨어뜨리는 결과를 가져온다는 것을 확인할 수 있었다.

\section{DNA 공여체수와 수용체수의 관계}

접합전달효율이 낮은 방선균의 경우 plasmid DNA의 공여 체로 사용되는 E. coli수와 수용체인 포자수의 비율이 접합전 달효율에 대단히 중요한 영향을 미친다[4]. 선행연구에 의하면 S. platensis의 경우 다른 방선균에 비해 접합전달효율이 낮을 것으로 판단되었다[3]. 그러므로 접합전달에 필요한 최적공여 체수를 조사하기 위해 Table 3에서 보는 바와 같이 공여체인 E. coli 수를 $2.5 \times 10^{6}$ 에서 $2.5 \times 10^{8}$ 까지 단계적으로 적용하였으며 수용체인 포자의 수도 $5 \times 10^{6}$ 에서 $1 \times 10^{8}$ 까지 사용하여 실험하 였다. 그 결과 DNA 공여체의 수와 수용체의 수가 모두 증가할 수록 접합전달의 효율이 전체적으로 증가하는 경향을 보였다. 또 포자수가 $5 \times 10^{6}$ 일 때 $E$. colliㄱㄱㅏ $2.5 \times 10^{6}$ 이하이면 접합전달 이 일어나지 않지만 $E . \operatorname{coli} i$ 구가 $5 \times 10^{7}$ 이상이면 모든 포자수의

Table 3. Effects of the number of E. coli donor cells on transconjugation efficiency

\begin{tabular}{|c|c|c|c|c|}
\hline \multirow{3}{*}{$\begin{array}{c}\text { Number of } \\
\text { recipient } \\
\text { spores }\end{array}$} & \multicolumn{4}{|c|}{ Transconjugation frequency $^{a}$} \\
\hline & \multicolumn{4}{|c|}{ Number of E. coli ET12567/pUZ8002(pSET152) } \\
\hline & $2.5 \times 10^{6}$ & $2.5 \times 10^{7}$ & $5 \times 10^{7}$ & $2.5 \times 10^{8}$ \\
\hline $5 \times 10^{6}$ & - & $1.8 \times 10^{-6}$ & $2.8 \times 10^{-4}$ & $3.3 \times 10^{-4}$ \\
\hline $1 \times 10^{7}$ & $2.0 \times 10^{-7}$ & $2.3 \times 10^{-6}$ & $3.0 \times 10^{-4}$ & $3.2 \times 10^{-4}$ \\
\hline $1 \times 10^{8}$ & $2.5 \times 10^{-7}$ & $2.4 \times 10^{-6}$ & $3.3 \times 10^{-4}$ & $3.2 \times 10^{-4}$ \\
\hline
\end{tabular}

${ }^{\mathrm{a}}$ Values represent average frequencies from three independent experiments.

- indicates no exconjugant. 
조건에서 접합전달효율이 크게 증가한다는 것을 확인할 수 있었다. 그러나 E. colili가 5 배 많은 $5 \times 10^{8}$ 에서는 $5 \times 10^{7}$ 와 크게 차이가 없었다. 따라서 S. platensis의 접합전달을 위한 최적 E. coli수는 $5 \times 10^{7}$ 이며 $2.5 \times 10^{7}$ 이상의 공여체가 접합전달을 위 해 필요하다는 것도 확인하였다.

\section{배지에 첨가되는 $\mathrm{MgCl}_{2}$ 의 최적농도}

배지에 $\mathrm{MgCl}_{2}$ 의 첨가유무는 접합전달효율에 큰 영향을 미 치게 되며 $10 \mathrm{mM}$ 의 $\mathrm{MgCl}_{2}$ 가 일반적으로 배지에 첨가되어 왔 다[15]. 그러나 최근 $K$ setae의 연구결과[4]에 따르면 ISP4배지 에 $50 \mathrm{mM}$ 의 $\mathrm{MgCl}_{2}$ 가 첨가되었 때 무첨가와 $10 \mathrm{mM}$ 첨가의 경우에 비해 각각 3.8 배와 3.3 배 높은 접합전달효율을 보였다. 이러한 결과는 방선균의 종류에 따라 최적농도도 달라질 수 있다는 것을 의미한다. 그러므로 S. platensis에 대한 $\mathrm{MgCl}_{2}$ 의 최적 첨가농도를 확인하기 위해 최적배지로 선정된 $\mathrm{MS}$ 배지에 0 60 mM까지 다양한 농도의 $\mathrm{MgCl}_{2}$ 를 첨가하여 접합전달을 진행하였다. 그 결과 Table 4 에서 보는 바와 같이 $\mathrm{MgCl}_{2}$ 를 첨가 하지 않은 실험군에 비해 첨가농도가 증가할수록 접합전달효 율이 높아지는 경향을 관찰할 수 있었다. $50 \mathrm{mM}$ 의 $\mathrm{MgCl}_{2}$ 를 첨가했을 때 $6.4 \times 10^{-6}$ 로 가장 높은 접합전달효율을 보였는데 무 첨가군에 비해 183 배나 높았으며 $10 \mathrm{mM}$ 첨가에 비해서도 3.2 배 높았다. 이러한 결과는 $K s \mathrm{setae}$ 의 연구결과와 매우 유사한 것으로 S. platensis의 접합전달을 위해서는 $\mathrm{MS}$ 배지에 $50 \mathrm{mM}$ $\mathrm{MgCl}_{2}$ 을 첨가하는 것이 최적 농도라는 것을 확인할 수 있었다. 지금까지의 연구를 통해 확인된 S. platensis를 위한 최적 접합전달 조건들은 접합전달용 배지로 $50 \mathrm{mM} \mathrm{MgCl}$ 가 첨가 된 MS배지를 사용하고 열처리하지 않은 $1 \times 10^{8}$ 포자와 DNA 공여체로써 $5 \times 10^{7} \mathrm{E}$. coli를 사용하는 것이다. 따라서 본 조건 들을 모두 적용한 결과 $9.4 \times 10^{-4}$ 이라는 높은 접합전달효율을 획득할 수 있었다. 이것은 Table 1과 같은 초기조건에 비해 400 배 이상 향상된 결과로써 특히 부위-특이적 재조합보다 100 배 이상 높은 형질전환효율을 요구하는 상동 재조합 (homologous recombination) [7]에도 충분히 사용 가능하다

Table 4. Effects of $\mathrm{MgCl}_{2}$ concentration in MS medium on the transconjugation efficiency

\begin{tabular}{cc}
\hline $\begin{array}{c}\text { Concentration of } \mathrm{MgCl}_{2} \\
\text { added in MS medium }(\mathrm{mM})\end{array}$ & $\begin{array}{c}\text { Transconjugation } \\
\text { frequencya }\end{array}$ \\
\hline 0 & $3.5 \times 10^{-8}$ \\
10 & $2.0 \times 10^{-6}$ \\
20 & $2.5 \times 10^{-6}$ \\
30 & $2.9 \times 10^{-6}$ \\
40 & $4.3 \times 10^{-6}$ \\
50 & $6.4 \times 10^{-6}$ \\
60 & $5.8 \times 10^{-6}$ \\
\hline
\end{tabular}

${ }^{\mathrm{a}}$ Values represent average frequencies from three independent experiments.
는 것을 확인하였다.

\section{attB site의 특징}

본 연구에 사용된 pSET152벡터는 $p h C 31$ 유래의 attP site를 포함하고 있어 접합전달에 의해 방선균 내로 도입된 벡터는 integrase에 의해 chromosome의 attB site로 삽입되어 안정하 게 유지된다. 지금까지 연구된 결과에 의하면 attP site가 삽입 되는 곳은 단일 $a t t B$ site만이 아니라는 것이 밝혀졌다[20]. 따 라서 attP site가 삽입되는 S. platensis의 attB site에 대해 연구 하였다. 먼저 본 연구를 통해 얻어진 4 개의 접합전달체로부터 chromosome DNA를 각각 추출한 뒤 $K p n$ 으로 절단하고 pSET152의 Apr 내성유전자를 probe로 사용하여 Southern blot hybridization을 수행하였다. 그 결과 4 개의 접합전달체로 부터 동일한 단일밴드를 확인할 수 있었다(Fig. 2). 이것은 $S$. platensis의 chromosome내에 pSET152벡터가 삽입되는 곳이 한곳만 존재한다는 것을 시사하는 것이다. 또 attB site의 chromosome내의 위치와 염기서열을 확인하기 위해 PSET152가 삽입된 4 개의 접합전달체로부터 chromosome DNA를 각각 추출하여 Kpnl으로 처리한 뒤 agarose 전기영동을 통해 Southern blot에 확인된 단일밴드부근의 DNA단편을 회수하 였다. 얻어진 DNA는 self-ligation을 거쳐 E. coli XL10-Gold로 형질전환되었고, Apr $(50 \mu \mathrm{g} / \mathrm{ml})$ 가 첨가된 배지를 사용하여 형질전환체를 선별하여 attB site의 일부가 포함된 chromosome단편을 클로닝하였다. 얻어진 chromosome 단편의 염기 서열은 ATTPR primer를 이용하여 분석하였다. 그 결과 4 개의 접합전달체로부터 얻어진 $a t t B$ site의 right-region은 모두 동 일한 염기서열을 보였으며 accession number AB531501로 GeneBank에 등록되었다. 또 이미 밝혀진 다른 방선균 유래 attB site의 right-region 염기서열에 대해 $77.8 \% \sim 96.3 \%$ 의 상 동성을 보였으며 attB site의 chromosome내 위치는 $S$. platensis chromosome의 pirin 상동체를 코드하는 $\mathrm{ORF}$ 내에 위치 해 있었다(Fig. 3A). 그러나 attB site의 left-region에 대한 염기 서열은 확인할 수 없었는데 이러한 현상은 다른 연구에서도 보고된 봐 있다[17]. $a t t B$ site의 계통학적인 분석에서는 $S$. longisporoflavus의 $a t t B$ site와 가장 가까웠으며 S. aureofaciens

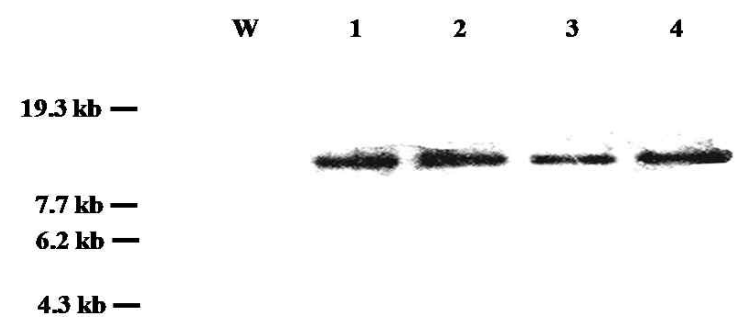

Fig. 2. Southern blot analysis of Kpnl-digested genomic DNA of wild-type strain and exconjugants. Lane W; wild-type S. platensis, lane 1-4; apramycin-resistant exconjugants of S. platensis. 
(A)

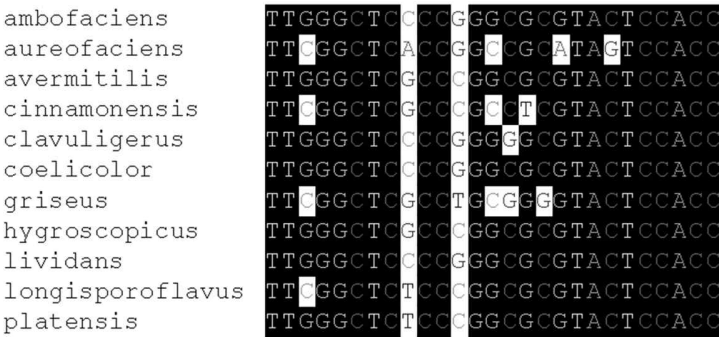

(B)

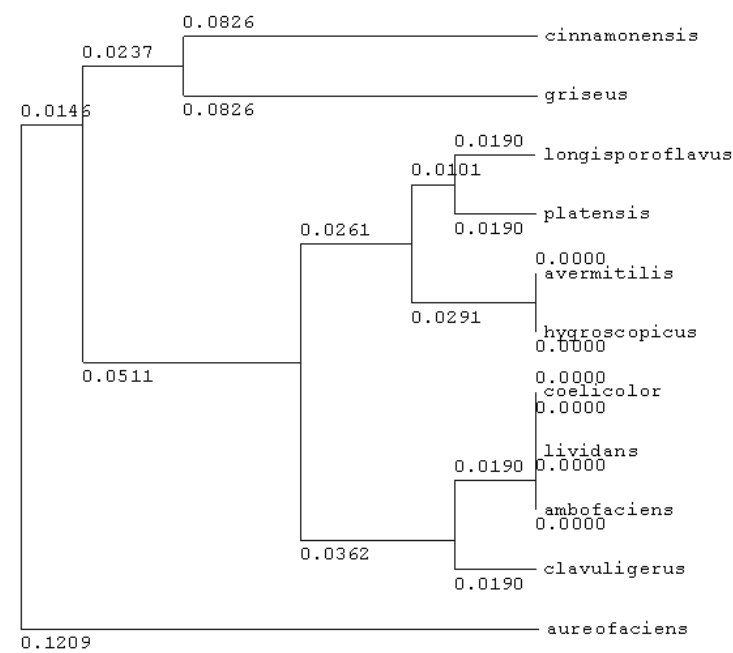

Fig. 3. Alignment of the $a t t B$ site sequences (A) and phylogenetic tree (B) among $S$. platensis and other actinomycetes: ambofaciens, $S$. ambofaciens, aureofaciens, $S$. aureofaciens, avermitilis, $S$. avermitilis MA-4680; cinnamonensis, $S$. cinnamonensis, clavuligerus, $S$. clavuligerus, coelicolor, $S$. coelicolor A3 (2) strain M145; griseus, S. griseus ATCC 12475; hygroscopicus, $S$. hygroscopicus NRRL5491; lividans, $S$. lividans 66 TK64; longisporoflavus, $S$. longisporoflavus 83E6; platensis, $S$. platensis YK-2 (this work). The alignment and the phylogenetic tree were created by GENETYX software (GENETYX Co., Tokyo, Japan). The numbers among actinomycetes in the phylogenetic tree indicate evolutionary relationship based on Kimura's two parameter model and neighbor-joining methods.

와 가장 멀었다(Fig. 3B). 또한 S. platensis chromosome의 $a t t B$ site에 pSET152벡터만의 삽입으로 S. platensis의 표현형이 변 화되는지를 확인하기위해 접합전달체와 야생주에 대하여 TGase 생산량과 형태분화를 확인해 보았으나 어떤 변화도 관 찰할 수 없었다(자료 미제시). 그러므로 본 연구에서 사용된 접합전달시스템은 S. platensis YK-2의 분자생물학적인 연구를 위해 대단히 안정적이고 효율적인 형질전환방법이라는 것이 확인되었다.

\section{감사의 글}

이 논문은 2009학년도 경남대학교 학술연구장려금 지원에
의한 것임.

\section{References}

1. Bailey, C. R. and D. J. Winstanley. 1986. Inhibition of restriction in Streptomyces clavuligerus by heat treatment. J. Gen. Microbiol. 132, 2945-2947.

2. Baltz, R. H. 1998. Genetic manipulation of antibiotic-producing Streptomyces. Trends Microbiol. 6, 76-82.

3. Bierman, M., R. Logan, K. O’Brien, E. T. Seno, R. N. Rao, and B. E. Schoner. 1992. Plasmid cloning vectors for the conjugal transfer of DNA from Escherichia coli to Streptomyces spp. Gene 116, 43-49.

4. Choi, S. U., C. K. Lee, Y. I. Hwang, H. Kinoshita, and T. Nihira. 2004. Intergeneric conjugal transfer of plasmid DNA from Escherichia coli to Kitasatospora setae, a bafilomycin $\mathrm{B}_{1}$ producer. Arch Microbiol. 181, 294-298.

5. Combes, P., R. Till, S. Bee, and M. C. M. Smith. 2002. The Streptomyces genome contains multiple pseudo-att $B$ sites for the $\phi C 31$-encoded site-specific recombination system. J. Bacteriol. 184, 5746-5752.

6. Engel, P. 1987. Plasmid transformation of Streptomyces tendae after heat attenuation of restriction. Appl. Environ. Microbiol. 53, 1-3.

7. Flett, F., V. Mersinias, and C. P. Smith. 1997. High efficiency intergeneric conjugal transfer of plasmid DNA from Escherichia coli to methyl DNA-restricting streptomycetes. FEMS Microbiol. Lett. 155, 223-229.

8. Folk, J. E. 1980. Transglutaminase. Annu. Rew. Biochem 49, 517-531.

9. Kanaji, T., H. Ozaki, T. Takao, H. Kawajiri, H. Ide, M. Motoki, and Y. Shimonishi. 1993. Primary structure of microbial transglutaminase from Streptoverticillium sp. Strain s-8112, J. Bio. Chem 268, 11565-11572.

10. Kieser, T., M. J. Bibb, M. J. Buttner, K. F. Chater, and D. A. Hopwood. 2000. Practical Streptomyces Genetics. The John Innes Foundation, Norwich, U.K.

11. Kitani, S., M. J. Bibb, T. Nihira, and Y. Yamada. 2000. Conjugal transfer of plasmid DNA from Escherichia coli to Streptomyces lavendulae FRI-5. J. Microbiol. Biotechnol. 10, 535-538.

12. Lorand, L. and S. M. Conrad. 1984. Transglutaminase. Mol. Cell Biochem 58, 9-35.

13. MacNeil, D. J. 1988. Characterization of a unique methyl-specific restriction system in Streptomyces avermitilis. J. Bacteriol. 170, 5607-5612.

14. Matsushima, P., M. C. Broughton, J. R. Turner, and R. H. Baltz. 1994. Conjugal transfer of cosmid DNA from Escherichia coli to Saccharopolyspora spinosa. effects of chromosomal insertions on macrolide A83543 production. Gene 146, 39-45.

15. Mazodier, P., R. Petter, and C. Thompson. 1989. Intergeneric conjugation between Escherichia coli and Streptomyces species. J. Bacteriol. 171, 3583-3585.

16. Motamedi, H., A. Shafiee, and S. J. Cai. 1995. Integrative 
vectors for heterologous gene expression in Streptomyces spp. Gene 160, 25-31.

17. Paranthaman, S. and K. Dharmalingam. 2003. Intergeneric conjugation in Streptomyces peucetius and Streptomyces sp. strain C5: Chromosomal integration and expression of recombinant plasmids carrying the chiC gene. Appl. Environ. Microbiol. 69, 84-91.

18. Rao, R. N., M. A. Richardson, and S. Kuhstoss. 1987. Cosmid shuttle vectors for cloning and analysis of Streptomyces DNA. Methods Enzymol. 153, 166-198.

19. Sambrook, J. and D. W. Russell. 2001. Molecular Cloning: A Laboratory Manual, 3rd eds. Cold Spring Harbor Laboratory, Cold Spring Harbor, New York, New York.
20. Smokvina, T., P. Mazodier, F. Boccard, C. J. Thompson, and M. Guerineau. 1990. Construction of a series of pSAM2based integrative vectors for use in actinomycetes. Gene 94, 53-59.

21. Stegmann, E., S. Pelzer, K. Wilken, and W. Wohlleben. 2001. Development of three different gene cloning systems for genetic investigation of the new species Amycolatopsis japonicum MG417-CF17, the ethylenediaminedisuccinic acid producer. J. Biotechnol. 92, 195-204.

22. Yeo, S. H., J. H. Yoon, D. G. Lee, and H. S. Kim. 2009. Screening and identification of a Streptomyces platensis YK-2, a new transglutaminase producer. J. Microbio. Biotechnol. 19, 588-595.

\section{초록 : Transglutaminase를 생산하는 Streptomyces platensis의 분자생물학적인 연구를 위한 접합 전달법 확립 \\ 배세정 · 조양호 · 최선욱* \\ (경남대학교 식품생명학과)}

식품단백질의 물성과 기능성을 개선시켜 산업적인 가치가 매우 높은 TGase를 생산하는 S. platensis YK-2의 분자 유전학적인 연구를 위해 형질전환방법을 확립하였으며 본 연구를 위해 도입된 방법은 대장균을 plasmid $\mathrm{DNA}$ 의 공여체로, S. platensis의 포자를 수용체로 사용하는 접합전달법이다. S. platensis를 위한 최적 접합전달조 건은 $50 \mathrm{mM}$ 의 $\mathrm{MgCl}_{2}$ 를 첨가한 $\mathrm{MS}$ 배지에 열처리를 하지 않은 포자와 $5 \times 10^{7}$ 의 plasmid DNA 공여체인 $E$. coli를 사용하는 것이다. 또 본 연구를 통해 얻어진 접합전달체의 attB site에 대한 분석을 통해 S. platensis chromosome 의 pirin 상동체를 코드하는 ORF내에 $a t t B$ site가 단일위치로 존재하고 있으며 이미 밝혀진 다른 방선균유래 $a t t B$ site의 염기서열에 대해 $77.8 \%$ $96.3 \%$ 의 상동성을 나타냈다. 